\title{
Lichens of Gujarat state, India with special reference to coastal habitats
}

\section{Nayaka $S^{1 *}$, Ingle $K_{K}^{1,2}$, Bajpai $R^{1}$, Rawal $J^{3}$, Upreti DK ${ }^{1}$ and Trivedi $S^{2}$}

\author{
${ }^{1}$ Lichenology Laboratory, CSIR-National Botanical Research Institute, Rana Pratap Marg, Lucknow-226001, India \\ ${ }^{2}$ Department of Botany, Motilal Vigyan Mahavidyalaya, Bhopal-462026, India \\ ${ }^{3}$ Jay Gurudev Career Academy, F-13, Astha Complex, Malgodun Road, Mehsana-384002, India
}

Nayaka S, Ingle KK, Bajpai R, Rawal JR, Upreti DK, Trivedi S 2013 - Lichens of Gujarat state, India with special reference to coastal habitats. Current Research in Environmental \& Applied Mycology 3(2), 222-229, doi 10.5943/cream/3/2/4

The present communication reports 39 lichen species from Gujarat state, belonging to 23 genera and 13 families. The lichens were collected mostly from 10 coastal districts of the state. A total of 21 species are new additions to the lichen mycota of Gujarat while 11 partially identified species are expected to be new to science. The paper emphasizes the uniqueness of coastal habitats in terms of interesting lichen mycota.

Key words - biodiversity - coastal area - lichenized fungi - mangrove

\section{Article Information}

Received 2 August 2013

Accepted 19 November 2013

Published online 5 December 2013

*Corresponding author: Sanjeeva Nayaka - e-mail - nayaka.sanjeeva@gmail.com

\section{Introduction}

The lichens are a group of terrestrial autotrophs which have an ability to grow on any stable substratum in any geographical region. The symbiotic association between a fungus and alga or cyanobacteria makes lichen a unique organism in several ways and they are among the organisms that can inhabit the harshest environments on earth (Kappen 1973). The extreme habitats also include rocky sea shores that are less suitable for other plants. The lichens are distributed throughout the world with an estimate of around 20000 species. India is a mega diversity country and represented by 2350 species of lichens with their rich diversity in Himalayas and Western Ghats. Several states and ecologically interesting sites in the country are either unexplored or under explored for the study of lichen diversity. Gujarat state is one such state where the current study is concentrated.

Gujarat state (Fig. 1) is situated on the western coast of India between co-ordinates $20^{\circ} 2^{\prime} \mathrm{N}-24^{\circ} 41^{\prime} \mathrm{N}$ latitude and $68^{\circ} 08^{\prime} \mathrm{E}-$ $74^{\circ} 23^{\prime} \mathrm{E}$ longitude. Geographically Gujarat is a large state with an area of $196,204 \mathrm{~km}^{2}$ which is $5.96 \%$ of the country's total geographical area. Natural ecosystem of Gujarat ranges from wetlands, grasslands and deciduous forests to deserts. Climate of the state is moderate with mean temperature ranging from $25^{\circ}$ to $27.5^{\circ} \mathrm{C}$ and the average annual rainfall ranging from 800 to $1000 \mathrm{~mm}$. Gujarat has many distinct biogeographic zones reflecting a wide range of ecological diversity. Several of the ecosystems have been represented in the Protected Areas where in situ conservation of species is being attempted. There are about 25 Protected Areas 
in the state covering an area of $16,902.41 \mathrm{~km}^{2}$, which accounts for $8.6 \%$ of the state's geographical area. The total floristic and faunal species in Gujarat includes 7048 species, including 4320 species of plants and 2728 species of animals representing terrestrial, freshwater and marine habitats (http://www.vigyanprasar.gov.in/radioserials/in dian_flora.pdf). It is evident that the lichens do not make their appearance in the biodiversity checklist of the state. From Gujarat, Singh \& Sinha (2010) documented only two species of lichens (Peltula euploca (Ach.) Poelt, and Roccella montagnei Bél.). Nayaka et al. (2010) reported five species of lichens from Gujarat of which Dirina paradoxa subsp. africana, Opegrapha arabica and $O$. varians are new records for India. Later on the specimens belonging to D. paradoxa subsp. africana were described as a new species Dirina indica Upreti \& Nayaka in Tehler et al. (2013). So far, only 7 lichen species were recorded from Gujarat.

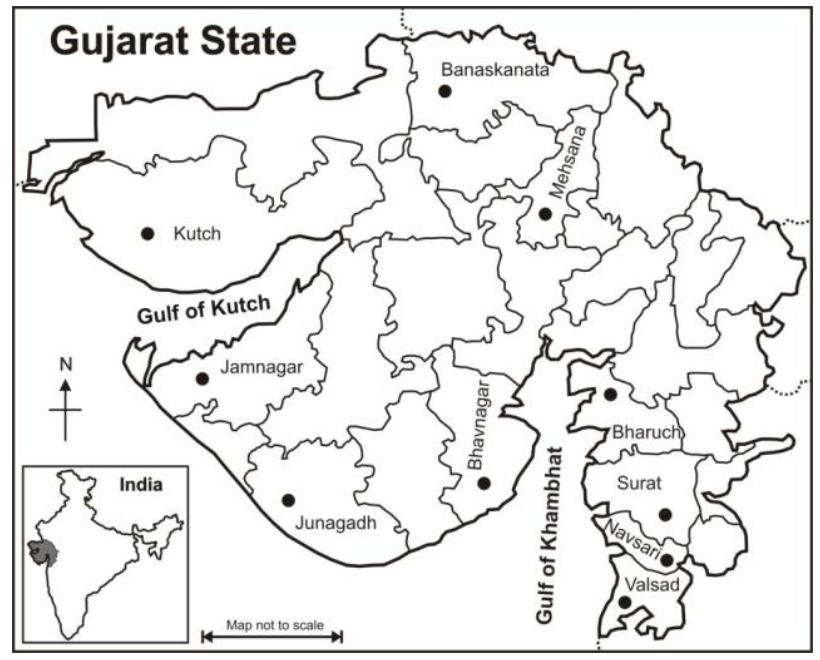

Fig. 1 - Map showing different districts of Gujarat state from where lichen representations are available.

The main reason for under taking lichenological studies in Gujarat state is not only under exploration of the area. What makes Gujarat an interesting region is its long coastline of $1324 \mathrm{~km}^{2}$ which has the second largest block of tidal forests after Sundarbans in terms of coverage area. The coastline shelters diverse ecosystems such as mangroves, coral reefs, estuaries and mudflats. From the studies carried out elsewhere it is clear that the coastal areas, especially mangroves have a rich and unique lichen mycota. Nakanishi (1964) studied epiphytic community growing on a mangrove tree Kandelia candel and described several interesting lichens and bryophytes. Stevens (1979) surveyed mangroves along nearly $4000 \mathrm{~km}$ coastline of eastern Australia and documented the distribution of 105 macrolichens that indicated the replacement of species within different genera with change in latitude. Remolina et al. (2000) reported interesting species of Peltigera from mangrove swamps of Colombian Caribbean coast. Gilbert (2001) studied the lichen mycota associated with twenty saline lagoons in England and observed that sites that were modified by the activity of man often held richer assemblages than ones in a more natural condition. Kathiresan and Qasim (2005) discussed in brief about the occurrence of lichens in mangrove forest of the world. Benatti \& Marcelli (2007) updated the list of lichens in southern Brazil and Itanhaém River mangrove and reported 81 lichen genera which illustrate the lichen richness in mangroves vegetation of tropical belt. According to Savillo (2009) lichens favourably grow on mangrove trees in inland streams compared to those growing near the river mouths and open seas. Trees in bays or in island partly surrounded by islets were seen to harbor lichen growth. Sonina (2012) investigated the diversity of lichens and their morphological adaptations in White and Barents Seas coast of Russian Arctic and documented 91 and 39 species respectively. From the southwestern coast of South Korea Zhang et al. (2012) recorded 12 species of lichens, among them 10 are crustose lichens and two are macrolichens. Sodamuk \& Mongkolsuk (2012) collected lichen specimens from 11 dominant trees in mangrove forest in Trat province of Thailand and identified 82 species which included twenty new records for the country and eighteen supposedly new to science.

In India very few studies on coastal and mangrove lichens are available. Mohan \& Hariharan (1999) studied the distribution pattern of lichens in Pichavaram mangrove forest in Tamil Nadu and reported 10 species. Similar to studies of Gilbert (2001), in 
Pichavaram mangroves the sites exposed to heavy anthropogenic disturbances favoured luxuriant growth of lichens. While surveying the coastal areas of Goa Nayaka et al. (2006) recorded 23 lichen species on coconut and areca nut trees. Jagadeesh Ram (2006) while studying the lichens of Sundarbans encountered a total of 165 lichen species with 8 new discoveries, 27 new records and 28 endemic taxa, which is a clear evidence for lichen richness in growing in mangrove forests. Sethy et al. (2012) studied the lichens growing on mangrove plants in Andaman Islands and reported twenty-nine species which included 14 are new records to the region and five were new records to India. Logesh et al. (2012) studied the lichen flora of Pichavaram and Muthupet mangroves of Southeast Coast of India and enumerated 21 species belonging to 14 genera and 10 families.

Another strong reason for taking up lichen study in Gujarat is the sensitivity of its coastal habitats for anthropogenic activities. Coastal environment plays a vital role in nation's economy by virtue of the resources, productive habitats and rich biodiversity. The coastal areas are assuming greater importance in recent years, owing to increasing human population, urbanization and accelerated developmental activities, which are putting tremendous pressure on the fragile coastal environment (Singh 2006). The coastal areas are also the place where natural disasters are experienced. The super cyclones had caused massive destruction along the coast of Gujarat in 1998 and its impact felt several kilometers inland. In addition with new policy of economic liberalization and encouragement of privatization, the Government of Gujarat has been evolving an ambitious plan for the development of its vast coastal zone for new ports, harbours, jetties, industries etc. This may result into high environmental burden on the coastal wetlands of the state. The lichens are very sensitive to microclimatic changes, air pollution and they are ones to vanish first from the disturb habitat. Therefore, owing to their unique diversity in coastal habitats the aim of the present study is to survey and document the lichens of Gujarat state before they vanish unnoticeably from nature due to anthropogenic disturbance.

\section{Materials \& Methods}

The present study was initiated with literature survey and scanning herbarium of CSIR - National Botanical Research Institute (LWG) for specimens collected earlier by researcher from Gujarat. It resulted in 90 specimens either completely or partially identified. The specimens belonged to Banaskantha, Kutch, Jamnagar and Mehsana districts. Fresh collection of lichens was made from coastal and mangrove forests in Bharuch, Bhavnagar, Junagadh, Navsari, Surat and Valsad districts (Fig. 1, Table 1).

The external morphology of the thallus was observed under a stereo-zoom microscope, Leica S8APO. Thin hand-cut sections of apothecia and thallus were mounted in plain water, cotton blue, $5 \% \mathrm{KOH}$ and iodine solution and observed under a compound microscope Leica DM500. For chemical spot tests, the usual reagents $\mathrm{K}(5 \%$ potassium hydroxide), $\mathrm{C}$ (aqueous solution of Calcium hypochlorite), and $\mathrm{Pd}$ (para-phenylenediamine) were used. Thin Layer Chromatography was performed in solvent system $\mathrm{C}$ following Orange et al. (2001). The specimens were identified up to their species level and authenticated following literatures of Awasthi (1991, 2007), Egea \& Torrente (1993), Ertz \& Diederich (2007), Ertz (2009), Joshi (2009), Nayaka (2004), Sparrius (2004), Tehler (1983, 1993), Upreti \& Singh (1999) and Upreti et al. (2010). The nomenclature and classification was updated following Lumbsch \& Huhndorf (2007). The identified specimens are preserved in herbarium of CSIR-National Botanical Research Institute, Lucknow (LWG).

\section{Results and discussion}

The list of lichens earlier reported from Gujarat is provided in Table 2 along with relevant literature. The lichen samples already available at the herbarium LWG served as an important base for our present study. Most of these specimens were partially identified. The identification of all specimens earlier deposited at LWG and as well as fresh collection revealed the occurrence of 39 taxa of belonging to 23 genera and 13 families. Out of the total 21 species were new records to lichen mycota of Gujarat while 11 were expected to be new to science (Table 3 ). 
Table 1 Details of sites from where the lichens were freshly collected.

\begin{tabular}{|c|c|c|c|c|c|c|}
\hline District & Taluk & Locality & Latitude & Longitude & $\begin{array}{c}\text { Altitude } \\
(\mathbf{m})\end{array}$ & Vegetation \\
\hline Navsari & Jalalpore & Dandi beach & N 205' 13.2" & E $072^{\circ} 47^{\prime} 49.7^{\prime \prime}$ & 7 & Prosopis juliflora \\
\hline Navsari & Jalalpore & $\begin{array}{l}\text { Dandi, near } \\
\text { GotadiyaKhadi Bridge }\end{array}$ & N $20^{\circ} 55^{\prime} 02.1^{\prime \prime}$ & E $072^{\circ} 49^{\prime} 26.6^{\prime \prime}$ & 13 & $\begin{array}{l}\text { Salvadora persica, } \\
\text { Prosopis juliflora and } \\
\text { Avicennia sp. }\end{array}$ \\
\hline Valsad & Valsad & Tithal port & N $20^{\circ} 32^{\prime} 14.9^{\prime \prime}$ & E $072^{\circ} 53^{\prime} 13.6^{\prime \prime}$ & 5.5 & Prosopis juliflora \\
\hline Surat & Choryasi & Dumas, near Hazira & N $21^{\circ} 04^{\prime} 46.2^{\prime \prime}$ & Е $072^{\circ} 42^{\prime} 28.3^{\prime \prime}$ & 12.3 & $\begin{array}{l}\text { Prosopis juliflora and } \\
\text { Avicennia sp. }\end{array}$ \\
\hline Surat & Choryasi & Dumas, near Hazira & N $21^{\circ} 05^{\prime} 40.5^{\prime \prime}$ & Е $072^{\circ} 42^{\prime} 11.6^{\prime \prime}$ & 23.6 & Azadirachta indica \\
\hline Surat & Olpad & Dandi village & N $21^{\circ} 19^{\prime} 28.9^{\prime \prime}$ & E $072^{\circ} 37^{\prime} 13.7^{\prime \prime}$ & 3 & $\begin{array}{l}\text { Sacred grove with } \\
\text { Prosopis juliflora }\end{array}$ \\
\hline Bharuch & Jambusar & Islampur village & N $21^{\circ} 58^{\prime} 10.5^{\prime \prime}$ & E $072^{\circ} 38^{\prime} 24.9^{\prime \prime}$ & 5 & Prosopis juliflora \\
\hline Bhavnagar & Ghogha & Ghogha village & N $21^{\circ} 40^{\prime} 22.9^{\prime \prime}$ & Е $072^{\circ} 17^{\prime} 07.4^{\prime \prime}$ & 3.2 & $\begin{array}{l}\text { Prosopis juliflora and } \\
\text { Avicennia sp. }\end{array}$ \\
\hline Bhavnagar & Talaja & Alang village & N $21^{\circ} 25^{\prime} 41.5^{\prime \prime}$ & E $072^{\circ} 11^{\prime} 43.8^{\prime \prime}$ & 20 & Ficus benghalensis \\
\hline Bhavnagar & Talaja & Alang village & N $21^{\circ} 25^{\prime} 15.9^{\prime \prime}$ & E $072^{\circ} 11^{\prime} 27.4^{\prime \prime}$ & 11.4 & $\begin{array}{l}\text { Mangifera indica and } \\
\text { Azadirachta indica }\end{array}$ \\
\hline Bhavnagar & Talaja & $\begin{array}{l}\text { Gopnath road, } 5 \mathrm{Km} \\
\text { before GopnathMahadeo } \\
\text { Temple }\end{array}$ & N $21^{\circ} 13^{\prime} 06.0^{\prime \prime}$ & Е $072^{\circ} 03^{\prime} 56.1^{\prime \prime}$ & 17 & $\begin{array}{l}\text { Cocos nucifera and } \\
\text { Mangifera indica }\end{array}$ \\
\hline Bhavnagar & Talaja & Jhanjmer & N $21^{\circ} 11^{\prime} 03.5^{\prime \prime}$ & Е $072^{\circ} 04^{\prime} 39.4^{\prime \prime}$ & 31 & Coastal rocks \\
\hline Bhavnagar & Mahuva & $\begin{array}{l}\text { Bhavani Temple, near } \\
\text { Bhavani beach }\end{array}$ & N $21^{\circ} 03^{\prime} 56.3^{\prime \prime}$ & E $071^{\circ} 48^{\prime} 26.0^{\prime \prime}$ & 65 & Prosopis juliflora \\
\hline Bhavnagar & Mahuva & $\begin{array}{l}\text { Katpur, near Bhavani } \\
\text { beach }\end{array}$ & N $21^{\circ} 02^{\prime} 47.1^{\prime \prime}$ & E $071^{\circ} 47^{\prime} 51.8^{\prime \prime}$ & 5 & Prosopis juliflora \\
\hline Bhavnagar & Mahuva & $5 \mathrm{Km}$ before Katpur & N $21^{\circ} 04^{\prime} 43.7^{\prime \prime}$ & E $071^{\circ} 46^{\prime} 33.5^{\prime \prime}$ & 13 & Cocos nucifera \\
\hline Junagadh & Kodinar & $\begin{array}{l}5 \mathrm{Km} \text { from Kodinar, near } \\
\text { GangnathMahadeo } \\
\text { Temple }\end{array}$ & N 204' $21.1^{\prime \prime}$ & E $070^{\circ} 42^{\prime} 12.9^{\prime \prime}$ & 7 & Prosopis juliflora \\
\hline Junagadh & Kodinar & $\begin{array}{l}4 \mathrm{Km} \text { from Kodinar, road } \\
\text { side area }\end{array}$ & N $20^{\circ} 46^{\prime} 41.5^{\prime \prime}$ & Е $070^{\circ} 43^{\prime} 26.4^{\prime \prime}$ & 8 & Cocos nucifera \\
\hline Junagadh & Kodinar & $\begin{array}{l}6 \mathrm{Km} \text { from Sarkhadi } \\
\text { village }\end{array}$ & N $20^{\circ} 41^{\prime} 48.0^{\prime \prime}$ & Е $070^{\circ} 49^{\prime} 59.2^{\prime \prime}$ & 3 & Coastal rocks \\
\hline Junagadh & Veraval & Veraval & N 2054'37.0" & E $070^{\circ} 21^{\prime} 10.1^{\prime \prime}$ & 5 & Coastal rocks \\
\hline Junagadh & Veraval & Veraval & N $20^{\circ} 55^{\prime} 03.4^{\prime \prime}$ & Е $070^{\circ} 20^{\prime} 33.3^{\prime \prime}$ & 8 & Prosopis juliflora trees \\
\hline
\end{tabular}

The uniqueness of lichen mycota in coastal areas of Gujarat lies in the dominance of crustose lichens represented by 26 species with maximum occurrence of Roccellacean members (11 species) (Fig. 2). Within the family Roccellaceae Opegrapha was more conspicuous with five taxa. Though there were few species of Roccellaceae in other mangrove studies carried out elsewhere in the world or India (Jagadeesh Ram 2006, Logesh et al. 2012), but such a dominance of Roccellacean members were not observed. Detailed report on lichens of mangroves in Andaman Islands completely lacked the family Roccellaceae (Sethy et al. 2012). Another uniqueness of lichen mycota in Gujarat is occurrence of many interesting lichens, belonging to genera Arthonia, Arthothelium, Heppia, Lempholemma, Opegrapha, Pertusaria, Porina and Rinodina may be new to science. There detailed study is still in progress in consultation of type specimens and world experts.

The other conspicuous lichen families in Gujarat are Arthoniaceae and Physciaceae represented by six and five species respectively. All the remaining families in the mycota are represented by one to two species. The region also has a good number of squamulose lichens with eight species while foliose, fruticose and leprose forms are poorly represented. Roccella belangeriana and $R$. montagnei are the two common fruticose 


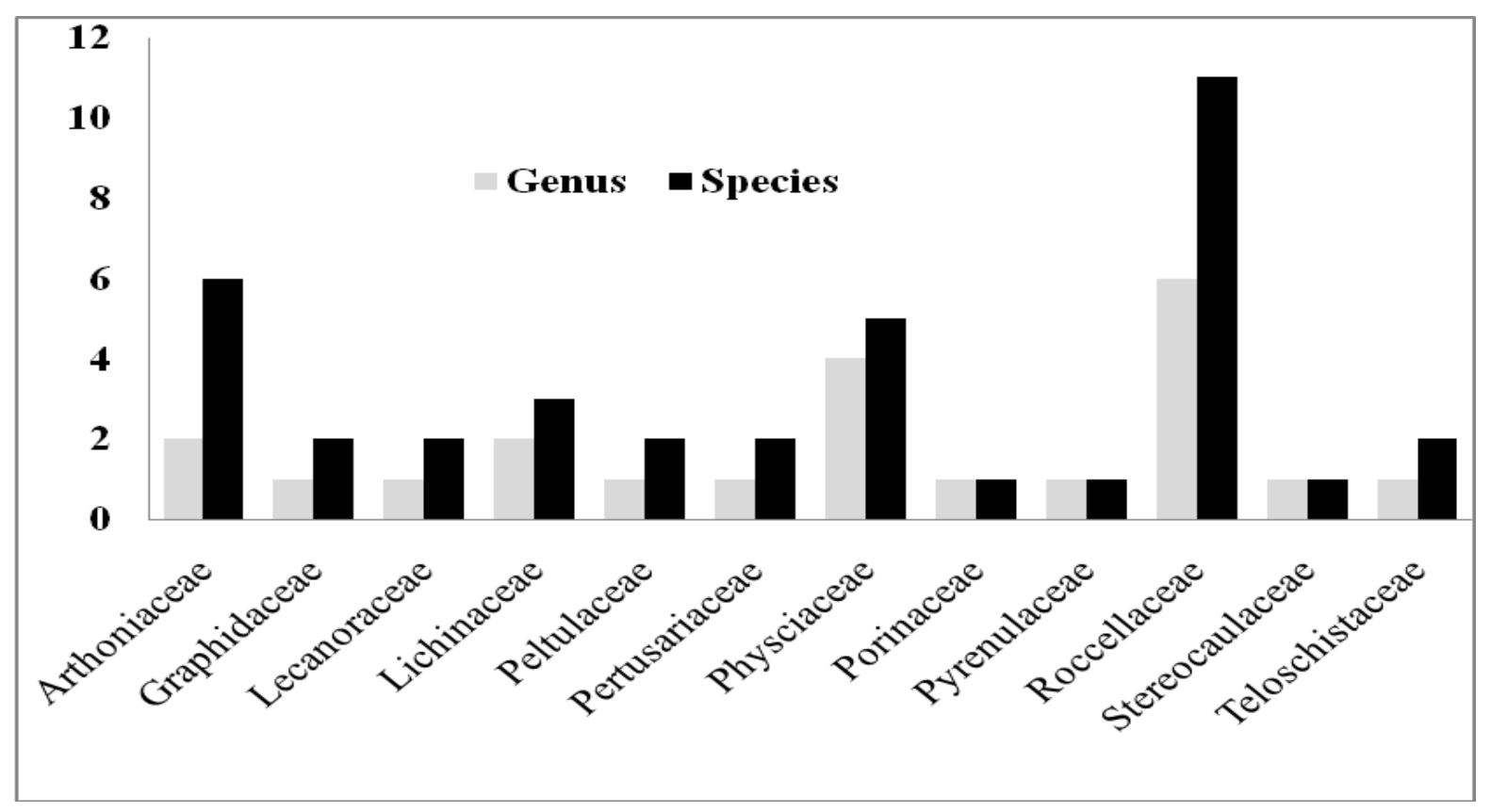

Fig 2 - Graph showing the diversity of species within families represented in Gujarat state.

Table 2 List of lichens earlier recorded from Gujarat state.

\begin{tabular}{lll}
\hline & Lichen taxa & References \\
\hline 1 & Cresponea flava (Vain.) Egea and Torrente & Nayaka et al.(2011) \\
2 & Dirina indica Upreti \& Nayaka (earlier reported as - D. & Tehler et al. (2013) \\
& paradoxa subsp. africana (Fée) Tehler in Nayaka et al.(2011)) & \\
3 & Enterographa pallidella (Nyl.) Redinger & Nayaka et al.(2011) \\
4 & Opegrapha arabica (Müll. Arg.) Vain. & Nayaka et al.(2011) \\
5 & O. varians (Müll. Arg.) Vain. & Nayaka et al.(2011) \\
6 & Peltula euploca (Ach.) Poelt & Singh \& Sinha (2010) \\
7 & Roccella montagnei Bél. & Singh \& Sinha (2010) \\
\hline
\end{tabular}

species in Gujarat, while Lepraria lobificansis the only leprose taxa. All the three species of foliose lichens were belonging to family Physciaceae and to genus Dirinaria and Hyperphyscia. The lichen mycota also represented of six cyanolichens, which have specialized physiology requiring more quantity of liquid water (not water vapous) for photosynthesis metabolic activity (Lange et al. 2001). Their adaptation and physiology in dry arid habitats of Gujarat is a subject for investigation. Among the 10 districts Banaskanata and Mehsana are inland localities without any connection of sea while others are located at coast of Arabian Sea. The district Jamnagar represents maximum number of 17 species of lichens while Bhavnagar and Junagadh districts included 15 and 8 species respectively (Table 3). In Jamnagar district maximum numbers of lichen specimens were collected from Marine National Park, which is the first national marine park of India. Among the mangrove and mangrove associated plants Avicennia marina, Ceriops tagal, Rhizophora mucronata and Salvadora persica growing in Gulf of Kutch attached to Jamnagar and Kutch districts harboured luxuriant growth of lichens, where as in the districts located around the Gulf of Khambhat (Bharuch, Bhavnagar, Navsari, Surat, Valsad) the major mangrove vegetation consisted of Avicennia did not host any lichens. The substratum for the growth of lichens at Gulf of Khambhat and inland included rocks, Azadirachta indica, Cocos nucifera, Ficus benghalensis, Mangifera indica, Phoenix sp., Prosopis juliflora and Salvadora persica. The mangrove associated tree Salvadora persica being a common host in coast of Gujarat harboured maximum growth of 11 lichen species, while Prosopis juliflora a 
Table 3 List of lichens and their distribution in different districts of Gujarat (Note: $\mathrm{Cr}=\mathrm{Crustose}$, $\mathrm{Fl}=$ Foliose, $\mathrm{Sq}=$ Squamulose, $\mathrm{L}=$ Leprose, $\mathrm{Fr}=$ Fruticose) .

\begin{tabular}{|c|c|c|c|c|c|c|c|c|c|c|c|c|c|}
\hline \multirow[b]{2}{*}{$\begin{array}{c}\text { S. } \\
\text { No. }\end{array}$} & \multirow[b]{2}{*}{ Lichen sp. } & \multirow[b]{2}{*}{ Family } & \multirow[b]{2}{*}{$\begin{array}{l}\Xi \\
0 \\
0 \\
0 \\
0 \\
0 \\
0 \\
0\end{array}$} & \multicolumn{10}{|c|}{ Districts of Gujarat } \\
\hline & & & & 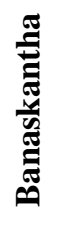 & 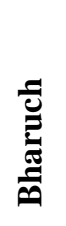 & 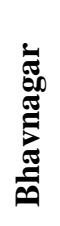 & $\underset{\Xi}{\Xi}$ & 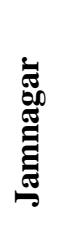 & 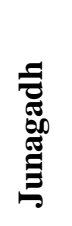 & 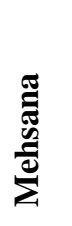 & $\begin{array}{l}\vec{B} \\
\mathbb{Z} \\
\vec{Z} \\
\vec{Z}\end{array}$ & 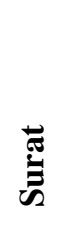 & $\frac{\vec{乛}}{\tilde{\sigma}}$ \\
\hline 1 & $\begin{array}{l}\text { Amandinea punctata (Hoffm.) Coppins \& } \\
\text { Scheid. }\end{array}$ & Physciaceae & $\mathrm{Cr}$ & & & + & & & & & & + & \\
\hline 2 & Arthonia sp. & Arthoniaceae & $\mathrm{Cr}$ & & & + & & & & & & & \\
\hline 3 & A. antillarum (Fée) Nyl. & Arthoniaceae & $\mathrm{Cr}$ & & & & & + & & & & & \\
\hline 4 & A cinnabarina (DC) Wallr. & Arthoniaceae & $\mathrm{Cr}$ & & & & & + & + & & & & \\
\hline 5 & A. dispersula $\mathrm{Nyl}$ & Arthoniaceae & $\mathrm{Cr}$ & & + & + & & & & & + & + & + \\
\hline 6 & A. medusula (Pers.) Nyl. & Arthoniaceae & $\mathrm{Cr}$ & & + & & + & + & & & + & + & + \\
\hline 7 & Arthothelium sp. & Arthoniaceae & $\mathrm{Cr}$ & & & + & & & & & & & \\
\hline 8 & Bactrospora sp. & Roccellaceae & $\mathrm{Cr}$ & & & & & + & & & & & \\
\hline 9 & Caloplaca cupulifera (Vain.) Zahlbr. & Teloschistaceae & $\mathrm{Cr}$ & & & & & & & + & & & \\
\hline 10 & C. squamosa (de Lesd.) Zahlbr. & Teloschistaceae & $\mathrm{Sq}$ & & & & + & & & & & & \\
\hline 11 & Cresponea flava (Vain.) Egea and Torrente & Roccellaceae & $\mathrm{Cr}$ & & & & & + & & & & & \\
\hline 12 & Dirina indica Upreti \& Nayaka & Roccellaceae & $\mathrm{Cr}$ & & & & & + & & & & & \\
\hline 13 & Dirinaria confluens (Fr.) D.D. Awasthi & Physciaceae & $\mathrm{Fl}$ & & & & & & & + & & & \\
\hline 14 & D. consimilis (Stirt.) D.D. Awasthi & Physciaceae & $\mathrm{Fl}$ & & & & & & + & & & & \\
\hline 15 & Enterographa pallidella (Nyl.) Redinger & Roccellaceae & $\mathrm{Cr}$ & & & & & + & & & & & \\
\hline 16 & Graphis sp. & Graphidaceae & $\mathrm{Cr}$ & & & & & + & & & & & \\
\hline 17 & G. striatula (Ach.) Spreng. & Graphidaceae & $\mathrm{Cr}$ & & & & & + & & & & & \\
\hline 18 & Heppia sp. & Heppiaceae & $\mathrm{Sq}$ & & & + & & & & & & & \\
\hline 19 & Hyperphyscia isidiata Moberg & Physciaceae & $\mathrm{Fl}$ & & & & & & & + & & & \\
\hline 20 & Lecanora achroa Nyl. in Cromb. & Lecanoraceae & $\mathrm{Cr}$ & & & + & & & & & & & \\
\hline 21 & L. interjecta Müll. Arg. & Lecanoraceae & $\mathrm{Cr}$ & & & + & & & & & & & \\
\hline 22 & Lempholemma sp. & Lichinaceae & $\mathrm{Sq}$ & & & + & & & + & & & & \\
\hline 23 & Lepraria lobificans Nyl. & Stereocaulaceae & $\mathrm{L}$ & & & & & + & & + & & & \\
\hline 24 & Opegrapha sp.1 & Roccellaceae & $\mathrm{Cr}$ & & & + & & & & & & & \\
\hline 25 & Opegrapha sp.2 & Roccellaceae & $\mathrm{Cr}$ & & & + & & & & & & & \\
\hline 26 & O. arabica (Müll. Arg.) Vain. & Roccellaceae & $\mathrm{Cr}$ & & & & & + & & & & & \\
\hline 27 & O. varians (Müll. Arg.) Vain. & Roccellaceae & $\mathrm{Cr}$ & & & & & + & & & & & \\
\hline 28 & O. vulgata Ach. & Roccellaceae & $\mathrm{Cr}$ & & & + & & + & & & & & \\
\hline 29 & Peltula euploca (Ach.) Poelt & Peltulaceae & $\mathrm{Sq}$ & + & & & & + & & & & + & \\
\hline 30 & P. placodizans (Zahlbr.) Wetmore & Peltulaceae & $\mathrm{Sq}$ & & & & & & & + & & & \\
\hline 31 & Pertusaria sp.1 & Pertusariaceae & $\mathrm{Cr}$ & & & & & & + & & & & \\
\hline 32 & Pertusaria sp. 2 & Pertusariaceae & $\mathrm{Cr}$ & & & & & & + & & & & \\
\hline 33 & Phylliscum indicum Upreti & Lichinaceae & $\mathrm{Sq}$ & & & + & & & + & & & + & \\
\hline 34 & P. testudineum Henssen & Lichinaceae & $\mathrm{Sq}$ & & & & & & + & & & & \\
\hline 35 & Porina sp. & Porinaceae & $\mathrm{Cr}$ & & & + & & & & & & & \\
\hline 36 & Rinodina sp. & Physciaceae & $\mathrm{Cr}$ & & & + & & & & & & & \\
\hline 37 & Roccella belangeriana D.D. Awasthi & Roccellaceae & $\mathrm{Fr}$ & & & & & + & & & & & \\
\hline 38 & R. montagnei Bél. em. D.D. Awasthi & Roccellaceae & $\mathrm{Fr}$ & & & & & + & & & & & \\
\hline 39 & $\begin{array}{l}\text { Sulcopyrenula staurospora (Tuck. ex H. } \\
\text { Willey) H. Harada }\end{array}$ & Pyrenulaceae & $\mathrm{Cr}$ & & & & & + & & & & & \\
\hline
\end{tabular}

dominant small tree distributed throughout the state hosted seven species. This also indicates the hostility of the substratum for the growth of lichens. The coastal rocks also supported luxuriantly growth of lichens as 16 species recorded from it; most of them are squamulose forms including Heppia, Lempholemma sp., Peltula euploca, P. placodizans, Phylliscum indicum and $P$. testudineum. The rocks, especially at Zanjmer taluka of Bhavnagar district supported some interesting lichens including possibly new species of Heppia and 
Pertusaria. Among all the lichen species recorded from Gujarat Arthonia dispersula and A. medusula found to be the most common and widely distributed species.

\section{Conclusion}

The current study being first report of lichens from Gujarat state will be very helpful as baseline for future studies in the state. The lichens being sensitive to microclimatic condition can be used as biomonitors keeping in view of anthropogenic disturbances in the state. The present study opens some of the interesting areas such as ecological difference governing the distribution of lichen in Gulfs of Kutch and Khambhat. The physiological responses and adaptation of cyanolichens in the coastal areas would be another interesting area for the future study. The current study encourages us to continue further study on lichens in remaining districts of Gujarat which would certainly reveal the complete picture of lichen diversity in the state.

\section{Acknowledgements}

We are thankful to Director, CSIRNational Botanical Research Institute, Lucknow for providing laboratory facilities. Ministry of Environment and Forests, New Delhi for financial assistance.

\section{References}

Awasthi DD. 1991 - A key to microlichens of India, Nepal and Sri Lanka. Bibliotheca Lichenologica 40, 1-337.

Awasthi DD. 2007 - A Compendium of the Macrolichens from India, Nepal and Sri Lanka.Bishen Singh Mahendra Pal Singh, Dehra Dun, India.1-580.

Benatti MN, Marcelli MP. 2007 - Gêneros de fungosliquenizados dos manguezais do Sul-Sudeste do Brasil, com enfoque no manguezal do Rio Itanhaém, Estado de São Paulo. Acta Botanica Brasilica 21(4), 863-878.

Egea JM, Torrente P. 1993 - Cresponea, a new genus of lichenized fungi in the order Arthoniales (Ascomycotina). Mycotaxon 48, 301-331.

Ertz D, Diederich P. 2007 - Revision of the Opegrapha species with muriform ascospores (previously Dictyographa) (lichenized Roccellaceae). Lichenologist 39(2), 143-151.

Ertz D. 2009 - Revision of the Corticolous Opegrapha Species from the Paleotropics. Bibliotheca Lichenologica No. 102. J. Cramer in der Gebrüder Borntraeger Verlagsbuchhandlung, Berlin and Stuttgart. 176.

Gilbert O. 2001 - The lichen flora of coastal saline lagoons in England. Lichenologist 33(5), 409-417.

Jagadeesh Ram TAM. 2006 - Investigation on the lichen flora of Sundarbans Biosphere Reserve, West Bengal. Gauhati University, Assam. Ph.D. Thesis.

Joshi Y. 2009 - Morphotaxonomic Studies on Lichen Family Teloschistaceae from India. Dept. of Botany, University of Kumaun, Nainital. Ph.D. Thesis.

Kappen L. 1973 - Response to extreme environments. The lichens. (Ahmadjian V, Hale ME eds), pp. 311-380. Academic press, New York.

Kathiresan K, Qasim SZ. 2005 - Biodiversity of Mangrove Ecosystems. Hindustan Publishing Corporation, New Delhi.

Lange OL, Green TGA, Heber U. 2001 Hydration-dependent photosynthetic production of lichens: what do laboratory studies tell us about field performance? Journal of Experimental Botany. 52(363), 2033-2042.

Logesh AR, Upreti DK, Kalaiselvam M, Nayaka S, Kathiresan K. 2012 - Lichen flora of Pichavaram and Muthupet mangrove (Southeast Coast of India). Mycosphere 3(5), 884-888.

Lumbsch HT, Huhndorf SM. (ed) 2007 Outline of Ascomycota. Myconet13, 158.

Mohan MS, Hariharan GN. 1999 - Lichen distribution pattern in Pichavaram. A preliminary study to indicate forest disturbance in mangroves of south India. Biology of lichens (Mukerji KG, Chamola BP, Upreti DK, Upadhyay RK eds). Aravali Books International, New Delhi. 283-296.

Nakanishi S. 1964 - An epiphytic community on the mangrove tree, Kandelia candel. Hikobia 4(1-2), 124. 
Nayaka S, Upreti DK, Phatak S, Samuel C. 2006 - Preliminary observation on lichen flora of coconut and arecanut orchards of Goa, India. Phytotaxonomy6, 23-25.

Nayaka S, Upreti DK, Punjani B, Dubey U, Rawal J. 2010 - New records and notes on some interesting lichens of family Roccellaceae from India. Phytotaxonomy 10, 127-133.

Nayaka S. 2004 - Revisionary Studies on Lichen Genus Lecanora sensu lato in India. Dept. of Botany, Dr. R.M.L Avadh Univeristy, Faizabad. Ph.D. Thesis.

Orange A, James PW, White FJ. 2001 Microchemical methods for the identification of lichens. British Lichen Society. 1-101.

Remolina AD, Muñoz SA, León AR. 2000 New lichen in the mangrove swamps of the Colombian Caribbean coast. Revista de Biologia Tropical 48(2/3), 719.

Savillo I. 2009 - Lichens in mangroves. In SWS Annual Meeting Abstracts. Madison, WI. 189.

Sethy PP, Pandit GS, Sharma BO. 2012 Lichens on mangrove plants in Andman Island, India. Mycosphere 3(4), 476-484.

Singh HS. 2006 - Mangroves and their Environment (With emphasis on Mangroves in Gujarat). Gujarat Forest Department, GFRI, Gandhinagar.

Singh KP, Sinha GP. 2010 - Indian Lichens: An Annotated Checklist. Government of India.Botanical Survey of India. Shiv Offset Press, Dehra Dun. 1-571.

Sodamuk M, Mongkolsuk P. 2012 - Lichens in Mangrove Forest at Ban Pak Klong Num Chiew Muang District, Trat Province. The $6^{\text {th }}$ Thai Mycological Conference,
Bangkok, Thailand. 35.

Sonina AV. 2012 - Epilithic lichens and their morphological adaptations to the conditions of the White and Barents Seas coast (Rusian Arctic). Czech polar reports 2(2): 109-116.

Sparrius LB. 2004 - A Monograph of Enterographa and Sclerophyton. Bibliotheca Lichenologica, 89, J. Cramer, Berlin, Stuttgart. 137.

Stevens GN. 1979 - Distribution and related ecology of macrolichens on mangroves on the east Australian coast. Lichenologist 11, 293-305.

Tehler A, Ertz D, Irestedt M. 2013 - The genus Dirina (Roccellaceae, Arthoniales) revisited. The Lichenologist 45(4), 427476.

Tehler A. 1983 - The genera Dirina and Roccellina. Opera Botanica 70, 1-86.

Tehler A. 1993 - The genus Sigridea (Roccellaceae, Arthoniales, Euascomycetidae). Nova Hedwigia 57(34), 417-435.

Upreti DK, Joshi Y, Bajpai R. 2010 - New records of lichens growing on monuments in central India. Geophytology 38 (1-2), 37-40.

Upreti DK, Singh A. 1999 - Lichen genus Anthracothecium from India subcontinent. Biology of Lichens (Mukerji KG, Chamola BP, Upreti DK, Upadhyay RK eds), Aravali Books International, New Delhi. 343 - 386.

Zhang LL, Wang XY, Zhao ZT, Hur JS. 2012 - Lichens newly recorded from the South Korean coast. Mycotaxon. Vol 122, 421432. 